\title{
Flüt Öğrencilerinin Ses Elde Etmede Kullandıkları Parmak Pozisyonlarının Bilişsel ve Devinişsel Beceriler Açısından İncelenmesi
}

\author{
Analysis of Finger Positions of Flute Learners while Using for \\ Acquiring Sound in the Sense of Cognitive and Psychomotor Skills \\ Özge GENÇEL ATAMAN* \\ • Geliş Tarihi: 12.02.2019 • Kabul Tarihi: 04.11.2019 • Çevrimiçi Yayın Tarihi: 11.12.2019
}

\begin{abstract}
$\ddot{\mathbf{O} z}$
Bu araştırmanın amacı; Güzel Sanatlar Liseleri flüt öğrencilerinin flütten ses elde etmede kullandıkları parmak pozisyonlarının bilişsel ve devinişsel beceriler açısından incelenmesine yöneliktir. Araştırmanın örneklem grubu, kümeli örnekleme yöntemi ile seçilmiş 12 Güzel Sanatlar Lisesinin 11. ve 12. sınıflarında öğrenim görmekte olan 42 flüt öğrencisidir. Araştırmada veri toplama aracı olarak araştırmacı tarafından geliştirilen "Parmak Pozisyonlarına Yönelik Uygulama Çalışması" ve "Parmak Pozisyonlarına Yönelik Bilgi Testi” kullanılmıştır. Öğrencilerin 1., 2. ve 3. oktav sesleri elde etmede kullandıkları parmak pozisyonlarının bilişsel ve devinişsel beceriler açılarından değerlendirilmesinde frekans ve yüzde değerlerinden, ses elde etmede kullanılan parmak pozisyonlarına ilişkin devinişsel ve bilişsel beceri puanlarının karşılaştırılmasında Spearman Korelasyondan, öğrencilerin okumakta oldukları sınıf ve çalgılarını sevme/sevmeme durumları ile bilişsel ve devinişsel beceri puanlarının karşılaştırılmasında Mann Whitney U testinden, öğrencilerin flüt eğitimi alma süreleri ile bilişsel ve devinişsel beceri puanlarının karşılaştırılmasında da Kruskal Wallis testinden yararlanılmıştır. Araştırma sonucunda Güzel Sanatlar Liselerinde öğrenim görmekte olan flüt öğrencilerinin büyük çoğunluğunun ses elde etmede kullandıkları parmak pozisyonları açısından sıkıntı yaşadıkları ve yanlış davranışlar geliştirdikleri belirlenmiştir. Bu yanlış davranışlar bilişsel ve devinişsel beceriler açısından da büyük benzerlikler göstermektedir.
\end{abstract}

Anahtar sözcükler: Flüt eğitimi, parmak pozisyonları, bilişsel, devinişsel, beceri

Atıf:

Gençel Ataman, Ö. (2019). Flüt öğrencilerinin ses elde etmede kullandıkları parmak pozisyonlarının bilişsel ve devinişsel beceriler açısından incelenmesi. Pamukkale Üniversitesi Eğitim Fakültesi Dergisi, 49, 461-483. doi: 10.9779/pauefd.526046.

\footnotetext{
* Doç. Dr., Balıkesir Üniversitesi, ORCID ID: 0000-0002- 4621-8609, ogencelataman@gmail.com
} 


\begin{abstract}
The aim of this study is to analyze of finger positions of flute learners at Fine Arts High School while using for acquiring sound in the sense of cognitive and psychomotor skills. Sample group is composed of 42 flute learners at $11^{\text {th }}$ and $12^{\text {th }}$ classes at 12 Fine Arts High School chosen with cluster sampling method. "Practice Study for Finger Positions" and "Information Test for Finger Positions" which were developed by the researchers were used as data collection tool. Frequency (f) and percentage (\%) values were used for the evaluation of finger positions of learners who form the sample group in obtaining $1^{\text {st }}, 2^{\text {nd }}$ and $3^{\text {rd }}$ octave sounds in the sense of cognitive and psychomotor skills; Spearman Correlation was used in comparison of psychomotor and cognitive skill scores related to finger positions of flute learners in obtaining sound; Mann Whitney U test was used in comparison of grade of flute learners and status of loving/not loving their instrument and cognitive and psychomotor skill scores of their finger positions, Kruskal Wallis Test was used in comparison of period of flute training of learners and cognitive and psychomotor skill scores of their finger positions. Based on the findings of study, it was determined that great majority of flute learner who study at Fine Arts High School have problems in the sense of finger positions used for acquiring sound and develop wrong behaviours. These wrong behaviours are quite similar in the sense of cognitive and psychomotor behaviours.
\end{abstract}

Keywords: Flute education, finger positions, cognitive, psychomotor, skills.

\title{
Cited:
}

Gençel Ataman, Ö. (2019). Analysis of finger positions of flute learners while using for acquiring sound in the sense of cognitive and psychomotor skills. Pamukkale Üniversitesi Eğitim Fakültesi Dergisi, 49, 461-483. doi: 10.9779/pauefd.526046. 


\section{Giriş}

Müzik eğitimi bilişsel, duyuşsal ve devinişsel becerilerin iç içe olduğu bir eğitim alanıdır. Müzik eğitiminde bilişsel beceriler, müziksel bilgileri anlamayı, kavramayı, analiz etmeyi, tamamlamayı ve sentezlemeyi gerektirir ve zihinsel etkinliklerin yoğun olduğu bir alandır. Duyuşsal beceriler, müziğe karşı gösterilen duygusal davranışlar olarak değerlendirilir. Devinişsel beceriler ise zihin, kas koordinasyonu gerektiren davranışlar olarak tanımlanır (Yokuş ve Yokuş, 2010). Müzik eğitimi alanında çok önemli bir yere sahip olan çalg1 eğitimi, çalgı öğretimi yoluyla bireyler ve toplumların devinişsel, duyuşsal ve bilişsel davranışlarında kendi yaşantıları yoluyla ve kasıtlı olarak istendik değişiklikler oluşturma ya da yeni davranışlar kazandırma sürecidir (Uçan, 1994). İster mesleki ister özengen eğitimde olsun çalg1 eğitimi, devinişsel, duyuşsal ve bilişsel becerileri aynı önemle kapsayan bir eğitim boyutudur (Tufan ve Güdek, 2008). Bu bağlamda, müzik eğitiminin tüm alanlarında olduğu gibi çalgı eğitiminde de bilişsel, duyuşsal ve devinişsel alanlarda beceriler kazandırılmaktadır. Çalgı eğitiminde çalgı terimlerinin öğrenilmesi ve çalgı çalmada gereken tekniklerin kavranması bilişsel becerileri; çalgının sevilmesi, çalmaya ilişkin disiplinli çalışmaya yönelik bir tutum geliştirilmesi ve çalgı çalmaya yaşantıda yer verilmesi duyuşsal becerileri; çalgı çalmada iki elin eş güdümünün sağlanması ve çalgı çalmada karşılaşılan problemleri çözmeye yönelik davranışların kazanılması ise devinişsel becerileri kapsamaktadır (Özen, 2004).

Günümüzde flüt ailesinin en yaygın üyesi olarak kabul edilen Boehm mekanizmalı modern flüt, orkestralarda ve çalgı eğitiminde önemli bir yere sahiptir. Atak Yayla'ya (2000) göre çalg1 eğitimi içinde yer alan flüt eğitimi, flüt hakkında temel teknik, bilgi ve becerilerin kazanıldığı, birebir gerçekleşen planlı bir eğitim sürecidir. Akkuş’a (1996) göre flüt öğretimi, "flüt çalmayı öğrenmenin gerçekleşmesi ve flütü seslendirmek için bireyin davranışlarında teknik ve estetik nitelikli yeni davranışlar geliştirmek amacıyla uygulanan süreçlerin tümüdür" (Aktaran: Kurtaslan, 2011). Flüt eğitimi sürecinin temel amacı, öğrenciye flüt ile ilgili bilgi ve beceriler kazandırmak, ulusal ve uluslararası flüt repertuvarını tanıtmak ve öğrencide müzikal icra becerisi geliştirmektir. Bunların yanında duruş-tutuş, diyafram kullanımı, parmak pozisyonları, dil ve elin eşgüdümlü hareketi ve çalgıya özgü teknikler de öğrencilere kazandırılması gereken önemli beceriler arasındadır (Soytok, 2014).

Her çalgının kendine has teknik özellikleri bulunmaktadır. Ancak parmak pozisyonlarının doğru kullanımı, parmak pozisyonları arasındaki koordinasyon ve doğru geçişler neredeyse tüm çalgıların ortak teknik özellikleridir. Bresin ve Batel'e (2000) göre piyano gibi tek parmak hareketiyle ses üretilebilen çalgılarda bile doğru parmak kullanımının hız ve müzikal ifadenin doğruluğu üzerinde büyük etkisi vardır. Gençel Ataman'a (2017) göre nefesli çalgılarda üfleme tekniğinin yön ve genişliği ayrıca parmak pozisyonlarının doğru geçiş ve hareketleri önem taşımaktadır. Almeida, Chow, Smith ve Wolfe'un (2010) da belirttiği gibi nefesli çalgılarda ses üretme, perdelerin standart parmak pozisyonları kullanılarak kapatılıp açılmasıyla ve böylece boru boyunda meydana gelen değişiklikler yoluyla gerçekleşmektedir. Üfleme basınciyla ilişkili olarak flütte de her sesin kendine ait standart parmak pozisyonları bulunmaktadır. Han ve Lee'ye (2014) göre flütten doğru ses üretebilme, üfleme ve parmak pozisyonu gibi faktörlerden etkilenir. Bu durum flütten ses üretmede, üflenen havanın hızı ve elde edilecek sese ilişkin parmak pozisyonlarının önemini ortaya çıkarmaktadır (Han ve Lee, 2016). Diğer bir yandan, parmak pozisyonlarının doğru kullanımı yoluyla teknik egzersizlerin 
doğru bir şekilde çalınması, flüt eğitimi sürecinde iyi bir performans ve yüksek akademik başarı elde edilmesine katkı sağlamaktadır (Moratz, 2010). Bu nedenle flütte parmak pozisyonları ile ilgili tekniklerin kavranması bilişsel becerileri, flüt çalmada iki elin eş güdümlü olarak ses elde etmek için konumlandırılması da parmak pozisyonları ile ilgili devinişsel becerileri oluşturmaktadır.

Flütte 1. ve 2. oktavlardaki parmak pozisyonları C, C\#/D b, D, D\#/E b sesleri dışında değişiklik göstermez. 3. ve 4. oktavlardaki sesler ise diğer oktavlardan farklı olarak kendine özgü ve daha karmaşık parmak pozisyonlarıyla elde edilir. Ancak Han ve Lee'ye $(2016,2014)$ göre bazı flüt öğrencilerinin durumun farkında olmadan parmak pozisyonlarını birbirlerine karıştırdıkları ve sesleri kuralların dışında çalmaya çalıştıkları sıklıkla karşılaşılan bir durumdur. Diğer yandan Wye (1988) ve Hummel'in (2014) da belirttiği gibi,

- 2. oktav $\mathrm{C}, \mathrm{C} \sharp / \mathrm{D} b, \mathrm{D}, \mathrm{D} \sharp / \mathrm{E} b$ seslerini 1. oktav parmak pozisyonlarıyla çalmaya çalışmak, F\#/G b seslerinde sağ el yüzük parmağı yerine orta parmağı kullanmak, 2. oktav

$\mathrm{D}, \mathrm{D} \# / \mathrm{E} b$ seslerini çalarken sol el işaret parmağını basılı tutmak,

- 1. ve 2. oktav B b seslerini A\# pozisyonu ile elde etmeye çalışmak,

- 3. oktav $A \sharp / B b, B$ ve $C$ seslerini elde etmede sağ el serçe parmağ basıll tutmak gibi davranışlar flüt öğrencilerinde en yaygın olarak karşılaşılan yanlış parmak pozisyonu davranışları olarak bilinmektedir.

Oysaki dikkatli bir müziksel işitme yoluyla başlangıçta kolaylıkla fark edilip düzeltilebilecek bu davranışları ortadan kaldırabilmek için gösterilen çaba, flüt eğitimine yönelik olumsuz tutumların ortaya çıkmasına neden olabilmektedir. (Gençel Ataman, 2017). Üstün'e (2010) göre flüt eğitiminde bir tekniğin öğretilmesi, öğrencinin alışkanlık haline getirdiği yanlış bir davranışı ortadan kaldırmaktan çok daha kolaydır. Diğer yandan öğrencinin alışkanlık haline getirdiği yanlış davranışları düzeltme sürecinde düşündüğü teknik düzeyin istenilen biçimde gelişmemesini fark etmesi, öğrencinin çaba, istek ve hevesinin ortadan kalkmasına daha ileri bir boyutla başarısızlığına yol açabilmektedir.

Ülkemizde, ortaöğretim kademesinde mesleki müzik eğitiminin verildiği Güzel Sanatlar Liseleri, Eğitim Fakülteleri Müzik Eğitimi Anabilim Dallarının, Güzel Sanatlar Fakülteleri Müzik Bölümlerinin ve kısmen de olsa Devlet Konservatuvarlarının öğrenci kaynağı olan örgün eğitim kurumlarıdır. Güzel Sanatlar Liselerinde verilen müzik eğitiminin en yaygın alanlarından birini çalg1 eğitimi oluşturmaktadır. Gençel Ataman'a (2017) göre Güzel Sanatlar Liselerinde müzik eğitimine başlayan öğrenciler ilgi, istek ve bedensel yapılarına uyumlu bir çalgının eğitimini alarak bu kurumlardan mezun olmakta ve çoğunlukla da yükseköğretim kurumlarında aynı çalgının eğitimine devam etmektedirler. Bu kurumlarda gerçekleştirilen çalgı eğitiminin önemli bir kolunu da flüt eğitimi oluşturmaktadır. Mesleki müzik eğitiminin verildiği tüm kurumlarda olduğu gibi bu kurumlarda da flüt eğitimi, planlı olarak birebir gerçekleşen ve öğrencilerin flüt ile ilgili bilgi, beceri ve teknikleri kazandığı bir eğitimdir (Atak Yayla, 2000).

Flütten ses elde etmede kullanılan parmak pozisyonları gerek bilişsel gerekse devinişsel olarak flüt eğitiminin başlangıç aşamasında edinilmesi gereken temel beceriler arasında yer almaktadır. Mesleki müzik eğitimi alan bireylerin flüt eğitimine Güzel Sanatlar Liselerinde başladıkları düşünüldüğünde, parmak pozisyonları ile ilgili becerilerin bu kurumlarda verilen 
flüt eğitimi kapsamında incelenmesinin gerekliliği önem taşımaktadır. Ayrıca araştırma, flüt öğrencilerinin parmak pozisyonu davranışlarını bilişsel ve devinişsel açıdan ortaya koyan ulusal bir çalışmaya rastlanılmamış olması ve uluslararası çalışmaların da sınırlı sayıda olması nedeni ile de önemli sayılmaktadır. Bu bağlamda araştırmanın amacı; Güzel Sanatlar Liseleri flüt öğrencilerinin flütten ses elde etmede kullandıkları parmak pozisyonlarının bilişsel ve devinişsel beceriler açısından incelenmesine yöneliktir.

Araştırmanın amacı doğrultusunda;

- Flüt öğrencilerinin 1., 2. ve 3. oktav sesleri elde etmede kullandıkları parmak pozisyonlarına yönelik bilişsel ve devinişsel becerileri ne yöndedir?

- Öğrencilerin parmak pozisyonlarına ilişkin bilişsel ve devinişsel becerileri arasında bir ilişki var mıdır?

- Flüt öğrencilerinin okumakta oldukları sınıf ile parmak pozisyonlarına ilişkin bilişsel ve devinişsel becerileri arasında anlamlı bir ilişki var mıdır?

- Flüt öğrencilerinin flüt eğitimi alma süreleri ile parmak pozisyonlarına ilişkin bilişsel ve devinişsel becerileri arasında anlamlı bir ilişki var mıdır?

- Flüt öğrencilerinin çalgılarını sevme/sevmeme durumları ile parmak pozisyonlarına ilişkin bilişsel ve devinişsel becerileri arasında anlamlı bir ilişki var mıdır? Sorularına cevap aranmıştır.

\section{Yöntem}

Güzel Sanatlar Liseleri Müzik Bölümlerinde flüt eğitimi almakta olan 11. ve 12. sinıf öğrencilerinin, flütten ses elde etmek amacıyla kullandıkları parmak pozisyonlarının bilişsel ve devinişsel beceriler açısından incelenmesinin amaçlandığı bu araştırmada betimsel yöntem kullanılmıştır.

\section{Evren ve Örneklem}

Araştırmanın evrenini, ülkemizde flüt eğitiminin verildiği 62 Güzel Sanatlar Lisesinin 11. ve 12. Sınıflarında flüt eğitimi almakta olan 243 flüt öğrencisi oluşturmaktadır. Araştırmanın örneklem grubu, olasılıklı örnekleme yöntemlerinden kümeli örnekleme yöntemi ile belirlenmiştir. Kümeli örnekleme yöntemi; evrendeki birimlerin öncelikle coğrafi özellikleri itibarıly küme denilen alt gruplara ayrilıp daha sonra bu kümelerden rastlantısal olarak örnekleme dahil edilecek birimlerin tespit edilmesidir (Gürbüz ve Şahin, 2016). Bu bağlamda araştırmanın örneklem grubu, 2017-2018 Eğitim-Öğretim yılı bahar döneminde 7 coğrafi bölgeden kümeli örnekleme yöntemi ile seçilmiş toplam 12 Güzel Sanatlar Lisesinin 11. ve 12. sınıflarında öğrenim görmekte olan 42 flüt öğrencisinden oluşmaktadır. 
Tablo 1. Araştırmaya Katılan Güzel Sanatlar Liseleri

\begin{tabular}{lcc}
\hline \multicolumn{1}{c}{ Lise } & f & \% \\
\hline Adana Güzel Sanatlar Lisesi & 3 & 7,1 \\
Balıkesir Güzel Sanatlar Lisesi & 4 & 9,5 \\
Bingöl Güzel Sanatlar Lisesi & 3 & 7,1 \\
Diyarbakır Güzel Sanatlar Lisesi & 1 & 2,4 \\
Edirne Güzel Sanatlar Lisesi & 4 & 9,5 \\
Eskişehir Güzel Sanatlar Lisesi & 7 & 16,7 \\
Gaziantep Güzel Sanatlar Lisesi & 5 & 11,9 \\
Karabük Safranbolu Güzel Sanatlar Lisesi & 3 & 7,1 \\
Kütahya Güzel Sanatlar Lisesi & 3 & 7,1 \\
Muğla Güzel Sanatlar Lisesi & 5 & 11,9 \\
Samsun Güzel Sanatlar Lisesi & 1 & 2,4 \\
Tekirdağ Güzel Sanatlar Lisesi & 3 & 7,1 \\
\hline \multicolumn{1}{c}{ Toplam } & $\mathbf{4 2}$ & $\mathbf{1 0 0}$ \\
\hline
\end{tabular}

Tablo 1'de araştırmaya katılan 42 flüt öğrencisinin hangi Güzel Sanatlar Liselerinde öğrenim görmekte olduklarına yer verilmiştir. Tabloya göre flüt öğrencilerinin \% 16,7 oranıla Eskişehir Güzel Sanatlar Lisesinde, \% 11,9 oranlarıyla Gaziantep ve Muğla Güzel Sanatlar Liselerinde, \% 9,5 oranlarıyla Balıkesir ve Edirne Güzel Sanatlar Liselerinde, \%7,1 oranlarıyla Adana, Bingöl, Karabük, Kütahya ve Tekirdağ Güzel Sanatlar Liselerinde, \% 2,4 oranlarıyla ise Diyarbakır ve Samsun Güzel Sanatlar Liselerinde öğrenim görmekte oldukları anlaşılmaktadır.

Tablo 2. Flüt Öğrencilerine İlişkin Kişisel Bilgileri

\begin{tabular}{|c|c|c|}
\hline Sinıf & & \\
\hline 11. Sinıf & 21 & 50,0 \\
\hline 12. Sinif & 21 & 50,0 \\
\hline Toplam & 42 & 100 \\
\hline \multicolumn{3}{|c|}{ Flüt eğitimi alma süreleri } \\
\hline $1-3 \mathrm{y} 1 \mathrm{l}$ & 24 & 57,2 \\
\hline $4-6$ y1l & 17 & 40,5 \\
\hline 7 yıl ve üzeri & 1 & 2,3 \\
\hline Toplam & 42 & 100 \\
\hline \multicolumn{3}{|c|}{ Flüt öğrencilerinin çalgılarını sevme durumları } \\
\hline Evet & 41 & 97,6 \\
\hline Hayır & 1 & 2,4 \\
\hline Toplam & 42 & 100 \\
\hline
\end{tabular}

Tablo 2'ye göre, araştırmaya katılan Güzel Sanatlar Liseleri flüt öğrencilerinin \% 50,0'sinin 11. sınıf, \%50,0'sinin 12. sinıfta öğrenim görmekte oldukları, \%57,2'sinin 1-3 yı1, \% 40,5'inin 4-6 yıl ve \% 2,3'ünün de 7 y1l ve üzeri zaman aralıklarında flüt eğitimi almakta oldukları ve \% 97, 6'sının çalgılarını sevdikleri, \% 2,4'ünün ise çalgılarını sevmedikleri anlaşılmaktadır.

\section{Veri Toplama Araçları}

Araştırmada veri toplama aracı olarak araştırmacı tarafından geliştirilen Parmak Pozisyonlarına Yönelik Uygulama Çalışması (Ek 1) ve Parmak Pozisyonlarına Yönelik Bilgi Testinden (Ek 2) yararlanılmıştır. Seslendirmeye yönelik olarak hazırlanan uygulama çalışması öğrencilerin 
parmak pozisyonları ile ilgili devinişsel becerilerinin, bilgi testi ise öğrencilerin parmak pozisyonları ile ilgili bilişsel becerilerinin ölçülmesinde kullanılmıştır. Uygulama çalışması, bilgi testinde de yer alan 19 notanın öğrenciler tarafından seslendirilmesinin amaçlandığı uzun ses egzersizlerinden oluşmaktadır. Uygulama çalışmasının ardından öğrencilere verilen bilgi testi, test ile ilgili açıklama, sınıf, flüt eğitimi alma süresi ve çalgıyı sevme/sevmeme durumu gibi kişisel bilgiler ve çalışma kapsamında belirlenen 19 notanın flütte hangi parmak pozisyonları ile elde edilebileceğini içeren durum tespiti bölümlerinden oluşmaktadır. Bilgi testinin kolay anlaşılabilir olabilmesi amacıyla testin açıklama bölümünde, sol ve sağ ele ilişkin parmak numaralarına ve parmakların flüt üzerinde hangi numaralar ile konumlandığına ilişkin şekillere yer verilmiştir. Parmak pozisyonlarına yönelik bilgi testinin açıklamalar bölümünde yer alan ve flütte parmak numaralarını gösteren şekiller aşağıdaki gibidir.
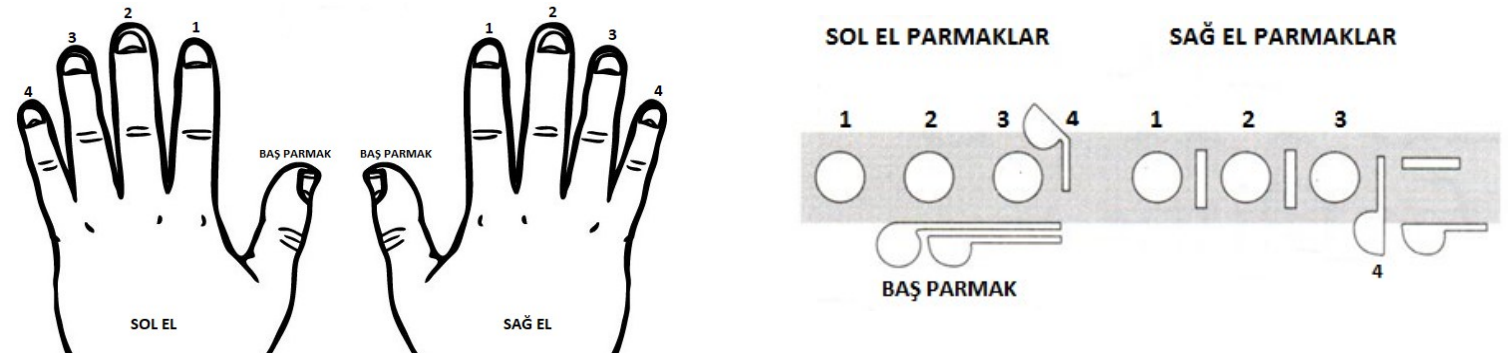

(Altes, 1986; Boehm, 2011; Harrison, 1982; Karşal, 2015; Moratz, 2010 )

\section{Şekil 1. Sol El/Sağ Eı Parmak Numaraları}

\section{Şekil 2. Flütte Parmak Numaraları}

Uygulama çalışması ve bilgi testinin geçerliğinin belirlenmesi amacıyla, 3'ü flüt eğitimcisi ve 1'i ölçme ve değerlendirme uzmanı olmak üzere 4 öğretim üyesinin görüşleri alınmıştır. Büyüköztürk'e (2008) göre güvenirlik katsayısının 0,70 ve daha yüksek bir değerde olması test puanlarının güvenirliği için yeterli görülmektedir. Uzman görüşleri doğrultusunda gerekli düzeltme ve düzenlemelerin yapıldığı veri toplama araçlarının 17 öğrenciye ön uygulama olarak uygulanması sonucunda, bilgi testinin Cronbach Alfa Güvenirlik Katsayıs1 0,957 uygulama çalışmasının Cronbach Alfa Güvenirlik Katsayısı ise 0,872 değerinde güvenilir bulunmuştur.

\section{Veri Toplama Araçlarının Uygulanması}

Araştırmanın veri toplama aşamasında öğrencilere öncelikle uygulama çalışması daha sonra bilgi testi uygulanmıştır. Uygulama çalışması, araştırmacı ya da lise flüt öğretmeni tarafindan görüntülü olarak kayıt edilmiş ve uygulama öncesinde öğrencilerden çalışma üzerinde yer alan yönergeyi okumaları istenmiştir. Görüntü kaydında öğrencilerin kimliklerini belirleyici görüntülere yer verilmeyip sadece çalma sırasındaki parmak pozisyonları kayıt edilmiştir. Uygulama çalışmasının ardından öğrencilerden öncelikle bilgi testine ilişkin açıklamayı okumaları ve kişisel bilgileri doldurmaları daha sonra teste yer alan 19 sesi elde etmek amacıyla kullandıkları parmak pozisyonlarını seslerin yanlarında verilen parmak pozisyonları tablosuna işaretlemeleri istenmiştir. 


\section{Verilerin Analizi}

Araştırmada elde edilen veriler, 3 flüt eğitimcisinin (öğretim üyesi) görüşleri doğrultusunda belirlenen ve araştırma kapsamındaki 19 sese ilişkin pozisyon kriterlerini içeren Bilişsel ve Devinişsel Beceri Değerlendirme Tablosu (Ek 3) aracıllı̆ıyla değerlendirilmiştir. Araştırmanın örneklemini oluşturan öğrencilere ilişkin uygulama çalışmalarını içeren görüntü kayıtları ve bilgi testleri 3 flüt eğitimcisi tarafından belirtilen değerlendirme tablosu aracıllı̆ıyla incelenmiştir. Puanlayıcı flüt eğitimcilerinin değerlendirmeleri kodlanarak SPSS 20 programına aktarılmış ve flüt eğitimcilerinin puan ortalamaları hesaplanmıştır. Araştırmada elde edilen verilerin normal dağılıma uygun olup olmadığını belirlemek amacıyla yapılan Kolmogorov Smirnov ve Shapiro Wilk Testi sonucunda, bilişsel ve devinişsel beceri puanlarına ait anlamlılık (p) değerlerinin 0,00 olduğu saptanmıştır. Anlamlılık değerlerinin 0,05'den küçük olması, incelenen maddelerin dağılımlarının normal olmadığını göstermektedir. Büyüköztürk'e (2008) göre "parametrik istatistikler, dağılımın normalliğini gerekli kılar". Bu nedenle çalışmadaki verilerin parametrik olmayan yöntemlerle analiz edilmesine karar verilmiştir. Verileri değerlendiren 3 puanlayıcının yapmış olduğu değerlendirmelerin tutarlılık ve güvenirliğini belirlemek amacıyla parametrik olmayan yöntemlerden Spearman Korelasyon kullanılmıştır. Puanlayıcıların değerlendirme puanları arasındaki ilişki Tablo 3 ve 4'te sunulmuştur.

Tablo 3. Puanlayıcıların Bilgi Testine Yönelik Puanları Arasındaki İlişki

\begin{tabular}{llccc}
\hline & Puanlayıcılar & 1. Puanlayıc & 2. Puanlayıcı & 3. Puanlayıcı \\
\hline \multirow{2}{*}{ 1. Puanlayıcı } & Korelasyon Katsayısı & 1,000 & & \\
& $\mathrm{p}$ & $0,00^{*}$ & & \\
\multirow{2}{*}{ 2. Puanlayıcı } & Korelasyon Katsayısı & 1,000 & 1,000 & \\
\multirow{2}{*}{ 3. Puanlayıcı } & $\mathrm{p}$ & $0,00^{*}$ & $0,00^{*}$ & \\
& Korelasyon Katsayısı & 1,000 & 1,000 & 1,000 \\
& $\mathrm{p}$ & $0,00^{*}$ & $0,00^{*}$ & $0,00^{*}$ \\
\hline $\mathrm{*}=0,000<0,05$ Spearman Korelasyon & &
\end{tabular}

Tablo 3'deki Spearman Korelasyon sonuçlarına göre, korelasyon katsayısı 1,000 ve p anlamlılık değeri 0,000 bulunmuştur. Büyüköztürk'e (2008) göre korelasyon katsayısının 1.00 olması ölçümler arasında mükemmel düzeyde pozitif bir ilişkiyi göstermektedir. Bu durum puanlayıcıların bilgi testine verdikleri puanlar arasında mükemmel düzeyde pozitif ve tutarlı bir ilişki olduğunu ortaya çıkarmaktadır.

Tablo 4. Puanlayıcıların Uygulama Çalışmasına Yönelik Puanları Arasındaki İlişki

\begin{tabular}{|c|c|c|c|c|}
\hline \multicolumn{2}{|c|}{ Puanlayıcılar } & 1. Puanlayıcı & 2. Puanlayıcı & 3. Puanlayıc \\
\hline \multirow{2}{*}{ 1. Puanlayıcı } & Korelasyon Katsayısı & 1,000 & & \\
\hline & $\mathrm{p}$ & $0,00 *$ & & \\
\hline \multirow{2}{*}{ 2. Puanlayıcı } & Korelasyon Katsayısı & 0,976 & 1,000 & \\
\hline & $\mathrm{p}$ & $0,00 *$ & $0,00 *$ & \\
\hline \multirow{2}{*}{ 3. Puanlayıcı } & Korelasyon Katsayısı & 0,988 & 0,955 & 1,000 \\
\hline & $\mathrm{p}$ & $0,00 *$ & $0,00 *$ & $0,00 *$ \\
\hline
\end{tabular}

$* \mathrm{p}=0,000<0,05$ Spearman Korelasyon

Tablo 4'e göre en düşük korelasyon katsayısı 0,955 en yüksek korelasyon katsayısı 1,000 ve p anlamlılık değeri de 0,000 bulunmuştur. Yine Büyüköztürk'e (2008) göre korelasyon 
katsayısının mutlak değer olarak 0,70 - 1,00 olması ölçümler arasında yüksek düzeyde bir ilişki olarak tanımlanmaktadır. Bu durum puanlayıcıların uygulama çalışmasına verdikleri puanlar arasında yüksek düzeyde ve tutarlı bir ilişki olduğunu ortaya çıkarmaktadır.

Puanlayıcıların bilgi testi ve uygulama çalışmasına ilişkin puanlarının tutarlığından yola çıkılarak; öğrencilerin 1., 2. ve 3. oktav sesleri elde etmede kullandıkları parmak pozisyonlarının bilişsel ve devinişsel beceriler açılarından değerlendirilmesinde frekans (f) ve yüzde (\%) değerlerinden, flüt öğrencilerinin ses elde etmede kullandıkları parmak pozisyonlarına ilişkin devinişsel ve bilişsel beceri puanlarının karşılaştırılmasında Spearman Korelasyondan, flüt öğrencilerinin okumakta oldukları sınıf ve çalgılarını sevme/sevmeme durumları ile parmak pozisyonlarına ilişkin bilişsel ve devinişsel beceri puanlarının karşılaştırılmasında Mann Whitney U Testi'nden, flüt öğrencilerinin flüt eğitimi alma süreleri ile parmak pozisyonlarına ilişkin bilişsel ve devinişsel beceri puanlarının karşılaştırılmasında da Kruskal Wallis Testi'nden yararlanılmıştır.

\section{Bulgular}

Tablo 5. Flüt Öğrencilerinin 1. Oktav Parmak Pozisyonlarına Yönelik Bilişsel ve Devinişsel Becerileri

\begin{tabular}{|c|c|c|c|c|c|c|}
\hline $\begin{array}{c}1 . \\
\text { Oktav } \\
\text { Sesler }\end{array}$ & Bilişsel Beceri & & & Devinişsel Beceri & & \\
\hline \multirow{5}{*}{$\mathbf{F} \#$} & & $\mathrm{f}$ & $\%$ & \multirow{5}{*}{$\begin{array}{l}\text { Sesi doğru pozisyon ile çalıyor. } \\
\text { Sesi sağ el 2. parmak ile } \\
\text { çalıyor. } \\
\text { Sesi çalamıyor. }\end{array}$} & $\mathrm{f}$ & $\%$ \\
\hline & Sesin pozisyonunu doğru biliyor. & 31 & 73,8 & & 31 & $\overline{73,8}$ \\
\hline & $\begin{array}{l}\text { Sesin pozisyonunu sağ el } 2 \text {. } \\
\text { parmak ile biliyor. }\end{array}$ & 11 & 26,2 & & 11 & 26,2 \\
\hline & Sesin pozisyonunu bilmiyor. & - & - & & - & - \\
\hline & Toplam & 42 & 100 & & 42 & 100 \\
\hline \multirow{4}{*}{$\mathbf{G} b$} & Sesin pozisyonunu doğru biliyor. & 31 & 73,8 & \multirow{4}{*}{$\begin{array}{l}\text { Sesi doğru pozisyon ile çalıyor. } \\
\text { Sesi sağ el 2. parmak ile } \\
\text { çalıyor. } \\
\text { Sesi çalamıyor. } \\
\text { Toplam }\end{array}$} & 31 & 73,8 \\
\hline & $\begin{array}{l}\text { Sesin pozisyonunu sağ el } 2 \text {. } \\
\text { parmak ile biliyor. }\end{array}$ & 11 & 26,2 & & 11 & 26,2 \\
\hline & Sesin pozisyonunu bilmiyor. & - & - & & - & - \\
\hline & Toplam & 42 & 100 & & 42 & 100 \\
\hline \multirow{3}{*}{$\mathbf{A} \#$} & Sesin pozisyonunu doğru biliyor. & 29 & 69,0 & Sesi doğru pozisyon ile çalıyor. & 29 & 69,0 \\
\hline & $\begin{array}{l}\text { Sesin pozisyonunu } \mathrm{B} b \\
\text { pozisyonu ile biliyor. }\end{array}$ & 13 & 31,0 & Sesi B b pozisyonu ile çalıyor. & 13 & 31,0 \\
\hline & $\begin{array}{c}\text { Sesin pozisyonunu bilmiyor. } \\
\text { Toplam }\end{array}$ & - & - & $\begin{array}{l}\text { Sesi çalamıyor. } \\
\text { Toplam }\end{array}$ & - & - \\
\hline \multirow{3}{*}{ B b } & Sesin pozisyonunu doğru biliyor. & 36 & 85,7 & Sesi doğru pozisyon ile çalıyor. & 33 & $\overline{78,6}$ \\
\hline & $\begin{array}{l}\text { Sesin pozisyonunu } A \# \text { pozisyonu } \\
\text { ile biliyor. }\end{array}$ & 6 & 14,3 & Sesi A\# pozisyonu ile çalıyor. & 9 & 21,4 \\
\hline & $\begin{array}{c}\text { Sesin pozisyonunu bilmiyor. } \\
\text { Toplam }\end{array}$ & - & $\begin{array}{c}- \\
100\end{array}$ & $\begin{array}{l}\text { Sesi çalamıyor. } \\
\text { Toplam }\end{array}$ & - & - \\
\hline
\end{tabular}

Tablo 5'de Güzel Sanatlar Liseleri flüt öğrencilerinin 1.oktav parmak pozisyonlarının bilişsel ve devinişsel beceriler açılarından değerlendirilmesine yer verilmiştir. $\mathrm{Bu}$ verilere göre, flüt öğrencilerinin \% 26,2'sinin F\# ve Gbseslerinin pozisyonlarını bilişsel beceri açısından sağ el 2. parmak ile bildikleri ve devinişsel beceri açısından da aynı oranla sağ el 2. parmak ile çaldıkları anlaşılmaktadır. Yine tablodan anlaşılacağı gibi öğrencilerin \% 31,0’inin A\# sesini bilişsel ve devinişsel beceriler açısından $\mathrm{Bb}$ pozisyonu ile bildikleri ve çaldıkları, \% 14,3'ünün $\mathrm{Bb}$ sesini 
bilişsel beceri açısından A\# pozisyonu ile bildikleri ve \% 21,4'ünün ise devinişsel beceri açısından A\# pozisyonu ile çaldıkları belirlenmiştir.

Tablo 6. Flüt Öğrencilerinin 2. Oktav Parmak Pozisyonlarına Yönelik Bilişsel ve Devinişsel Becerileri

\begin{tabular}{|c|c|c|c|c|c|c|}
\hline Oktav & Bilişsel Beceri & & & Devinişsel Beceri & & \\
\hline \multirow{5}{*}{$\mathrm{D} \#$} & & $\mathrm{f}$ & $\%$ & \multirow{3}{*}{$\begin{array}{l}\text { Sesi doğru pozisyon ile çalıyor. } \\
\text { Sesi sol el 1. parmağı basılı } \\
\text { tutarak çalıyor. }\end{array}$} & $f$ & $\%$ \\
\hline & Sesin pozisyonunu doğru biliyor. & 19 & 45,2 & & 13 & 31,0 \\
\hline & $\begin{array}{l}\text { Sesin pozisyonunu sol el } 1 . \\
\text { parmağ basıll tutarak biliyor. }\end{array}$ & 23 & 54,8 & & 28 & 66,7 \\
\hline & Pozisyonu bilmiyor. & - & - & Sesi çalamiyor. & 1 & 2,4 \\
\hline & Toplam & 42 & 100 & Toplam & 42 & 100 \\
\hline \multirow{4}{*}{$\mathrm{E} b$} & Sesin pozisyonunu doğru biliyor. & 18 & 42,9 & Sesi doğru pozisyon ile çalıyor. & 4 & 9,5 \\
\hline & $\begin{array}{l}\text { Sesin pozisyonunu sol el } 1 . \\
\text { parmağ basıll tutarak biliyor. }\end{array}$ & 24 & 57,1 & $\begin{array}{l}\text { Sesi sol el } 1 . \text { parmağ } \text { basilı } \\
\text { tutarak çalıyor. }\end{array}$ & 38 & 90,5 \\
\hline & Pozisyonu bilmiyor. & - & - & Sesi çalamiyor. & - & - \\
\hline & Toplam & 42 & 100 & Toplam & 42 & 100 \\
\hline \multirow{4}{*}{$\mathrm{F} \#$} & Sesin pozisyonunu doğru biliyor. & 31 & 73,8 & Sesi doğru pozisyon ile çalıyor. & 31 & 73,8 \\
\hline & $\begin{array}{l}\text { Sesin pozisyonunu sağ el } 2 \text {. } \\
\text { parmak ile biliyor. }\end{array}$ & 11 & 26,2 & $\begin{array}{l}\text { Sesi sağ el 2. parmak ile } \\
\text { çallyor. }\end{array}$ & 11 & 26,2 \\
\hline & Sesin pozisyonunu bilmiyor. & - & - & Sesi çalamıyor. & - & - \\
\hline & $\begin{array}{c}\text { Toplam } \\
\end{array}$ & 42 & 100 & Toplam & 42 & 100 \\
\hline \multirow{4}{*}{$\mathrm{G} b$} & Sesin pozisyonunu doğru biliyor. & 31 & 73,8 & Sesi doğru pozisyon ile çalıyor. & 30 & 71,4 \\
\hline & $\begin{array}{l}\text { Sesin pozisyonunu sağ el } 2 \text {. } \\
\text { parmak ile biliyor. }\end{array}$ & 10 & 23,8 & $\begin{array}{l}\text { Sesi sağ el } 2 \text {. parmak ile } \\
\text { çalıyor. }\end{array}$ & 11 & 26,2 \\
\hline & Sesin pozisyonunu bilmiyor. & 1 & 2,4 & Sesi çalamıyor. & 1 & 2,4 \\
\hline & Toplam & 42 & 100 & Toplam & 42 & 100 \\
\hline \multirow{4}{*}{$\mathrm{A} \#$} & Sesin pozisyonunu doğru biliyor. & 29 & 69,0 & Sesi doğru pozisyon ile çalıyor. & 29 & 69,0 \\
\hline & $\begin{array}{l}\text { Sesin pozisyonunu } \mathrm{B} \text { b pozisyonu } \\
\text { ile biliyor. }\end{array}$ & 13 & 31,0 & $\begin{array}{l}\text { Sesi B b pozisyonu ile } \\
\text { çalıyor. }\end{array}$ & 12 & 28,6 \\
\hline & Sesin pozisyonunu bilmiyor. & - & - & Sesi çalamıyor. & 1 & 2,4 \\
\hline & Toplam & 42 & 100 & Toplam & 42 & 100 \\
\hline \multirow{4}{*}{$\mathrm{B} b$} & Sesin pozisyonunu doğru biliyor. & 34 & 81,0 & Sesi doğru pozisyon ile çalıyor. & 33 & 78,6 \\
\hline & $\begin{array}{l}\text { Sesin pozisyonunu A\# pozisyonu } \\
\text { ile biliyor. }\end{array}$ & 8 & 19,0 & Sesi A\# pozisyonu ile çalıyor. & 9 & 21,4 \\
\hline & Sesin pozisyonunu bilmiyor. & - & - & Sesi çalamıyor. & - & - \\
\hline & Toplam & 42 & 100 & Toplam & 42 & 100 \\
\hline
\end{tabular}

Tablo 6'ya göre, flüt öğrencilerinin \% 54,8'inin D\# sesini bilişsel beceri açısından sol el 1. parmağı basılı tutarak bildiği, \% 66,7'sinin de devinişsel beceri açısından sol el 1. parmağı basılı tutarak çaldı ̆̆ı, Ebsesini \% 57,1'inin bilişsel beceri açısından sol el 1. parmağ basılı

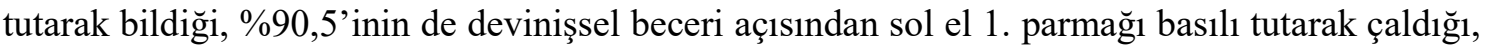
F\# sesini \% 26,2 oranlarıyla bilişsel ve devinişsel beceriler açısından sağ el 2. parmak ile bildikleri ve çaldıkları, \% 23,8'inin Gb sesini bilişsel beceri açısından să̆ el 2. parmak ile bildiği ve \% 26,2'sinin de devinişsel beceri açısından sağ el 2. parmak ile çaldığ 1 , \% 31,0'ının $\mathrm{A} \#$ sesini bilişsel beceri açısından $\mathrm{Bb}$ pozisyonu ile bildiği, \% 28,6'sının da devinişsel beceri 
açısından Bbpozisyonu çaldığı, \%19,0'ının Bbsesini bilişsel beceri açısından A\# pozisyonu ile bildiği ve \% 21,4'ünün de devinişsel beceri açısından A\# pozisyonu ile çaldığı anlaşılmaktadır.

Tablo 7. Flüt Öğrencilerinin 3. Oktav Parmak Pozisyonlarına Yönelik Bilişsel ve Devinişsel Becerileri

\begin{tabular}{|c|c|c|c|c|c|c|}
\hline $\begin{array}{l}3 . \\
\text { Oktav } \\
\text { Sesler }\end{array}$ & \multicolumn{3}{|l|}{ Bilişsel Beceri } & \multicolumn{3}{|l|}{ Devinişsel Beceri } \\
\hline \multirow{6}{*}{$\mathrm{D} \#$} & \multirow[b]{2}{*}{ Sesin pozisyonunu doğru biliyor. } & $\mathrm{f}$ & $\%$ & \multirow{3}{*}{$\begin{array}{l}\text { Sesi doğru pozisyon ile çalıyor. } \\
\text { Sesi sol el 4. parmağını } \\
\text { basmadan çalıyor. }\end{array}$} & \multirow{2}{*}{$\begin{array}{c}\mathrm{f} \\
37\end{array}$} & $\%$ \\
\hline & & 33 & 78,6 & & & 88,1 \\
\hline & $\begin{array}{l}\text { Sesin pozisyonunu sol el } 4 . \\
\text { parmağını basmadan biliyor. }\end{array}$ & 2 & 4,8 & & 2 & 4,8 \\
\hline & $\begin{array}{l}\text { Sesin pozisyonunu sol el } 1 . \\
\text { parmağ } 1 \text { basmadan biliyor. }\end{array}$ & 6 & 14,3 & $\begin{array}{l}\text { Sesi sol el 1. parmağını } \\
\text { basmadan çalıyor. }\end{array}$ & 3 & 7,1 \\
\hline & Sesin pozisyonunu bilmiyor. & 1 & 2,4 & Sesi çalamıyor. & - & - \\
\hline & Toplam & 42 & 100 & Toplam & 42 & 100 \\
\hline \multirow{5}{*}{$\mathrm{E} b$} & Sesin pozisyonunu doğru biliyor. & 34 & 81,0 & Sesi doğru pozisyon ile çalıyor. & 37 & 88,1 \\
\hline & $\begin{array}{l}\text { Sesin pozisyonunu sol el } 4 . \\
\text { parmağın basmadan biliyor. }\end{array}$ & 2 & 4,8 & $\begin{array}{l}\text { Sesi sol el 4. parmağını } \\
\text { basmadan çalıyor. }\end{array}$ & 5 & 11,9 \\
\hline & $\begin{array}{l}\text { Sesin pozisyonunu sol el } 1 . \\
\text { parmağ basmadan biliyor. }\end{array}$ & 5 & 11,9 & $\begin{array}{l}\text { Sesi sol el 1. parmağını } \\
\text { basmadan çalıyor. }\end{array}$ & - & - \\
\hline & Sesin pozisyonunu bilmiyor. & 1 & 2,4 & Sesi çalamıyor. & - & - \\
\hline & Toplam & 42 & 100 & Toplam & 42 & 100 \\
\hline \multirow{4}{*}{ F\# } & Sesin pozisyonunu doğru biliyor. & 33 & 78,6 & Sesi doğru pozisyon ile çalıyor. & 31 & 73,8 \\
\hline & $\begin{array}{l}\text { Sesin pozisyonunu sağ el } 2 \text {. } \\
\text { parmak ile biliyor. }\end{array}$ & 9 & 21,4 & $\begin{array}{l}\text { Sesi sağ el 2. parmak ile } \\
\text { çalıyor. }\end{array}$ & 10 & 23,8 \\
\hline & Sesin pozisyonunu bilmiyor. & & & Sesi çalamıyor. & 1 & - \\
\hline & Toplam & 42 & 100 & Toplam & 42 & 100 \\
\hline \multirow{4}{*}{$\mathrm{G} b$} & Sesin pozisyonunu doğru biliyor. & 30 & $\overline{71,4}$ & Sesi doğru pozisyon ile çalıyor. & 27 & 64,3 \\
\hline & $\begin{array}{l}\text { Sesin pozisyonunu sağ el } 2 \text {. } \\
\text { parmak ile biliyor. }\end{array}$ & 8 & 19,0 & $\begin{array}{l}\text { Sesi sağ el 2. parmak ile } \\
\text { çalıyor. }\end{array}$ & 10 & 23,8 \\
\hline & Sesin pozisyonunu bilmiyor. & 4 & 9,5 & Sesi çalamıyor. & 5 & 11,9 \\
\hline & Toplam & 42 & 100 & Toplam & 42 & 100 \\
\hline \multirow{5}{*}{$\mathrm{G} \#$} & Sesin pozisyonunu doğru biliyor. & 29 & 69,0 & Sesi doğru pozisyon ile çalıyor. & 31 & 73,8 \\
\hline & $\begin{array}{l}\text { Sesin pozisyonunu sol el } 1 \text {. } \\
\text { parmağını basılı tutarak biliyor. }\end{array}$ & 9 & 21,4 & $\begin{array}{l}\text { Sesi sol el 1. parmağını basılı } \\
\text { tutarak çalıyor. }\end{array}$ & 8 & 19,0 \\
\hline & $\begin{array}{l}\text { Sesin pozisyonunu sol el } \\
\text { başparmağını basilı tutarak biliyor. }\end{array}$ & 2 & 4,8 & $\begin{array}{l}\text { Sesi sol el başparmağını basıll } \\
\text { tutarak çalıyor. }\end{array}$ & 2 & 4,8 \\
\hline & Sesin pozisyonunu bilmiyor. & 2 & 4,8 & Sesi çalamıyor. & 1 & 2,4 \\
\hline & $\begin{array}{c}\text { Toplam } \\
\end{array}$ & 42 & 100 & Toplam & 42 & 100 \\
\hline \multirow{5}{*}{$A b$} & Sesin pozisyonunu doğru biliyor. & 26 & 61,9 & Sesi doğru pozisyon ile çalıyor. & 26 & 61,9 \\
\hline & $\begin{array}{l}\text { Sesin pozisyonunu sol el } 1 . \\
\text { parmağını basılı tutarak biliyor. }\end{array}$ & 7 & 16,7 & $\begin{array}{l}\text { Sesi sol el 1. parmağını basılı } \\
\text { tutarak çalıyor. }\end{array}$ & 6 & 14,3 \\
\hline & $\begin{array}{l}\text { Sesin pozisyonunu sol el } \\
\text { başparmağını basilı tutarak biliyor. }\end{array}$ & - & - & $\begin{array}{l}\text { Sesi sol el başparmağını basılı } \\
\text { tutarak çalıyor. }\end{array}$ & 3 & 7,1 \\
\hline & Sesin pozisyonunu bilmiyor. & 9 & 21,4 & Sesi çalamıyor. & 7 & 16,7 \\
\hline & Toplam & 42 & 100 & Toplam & 42 & 100 \\
\hline \multirow{3}{*}{ A\# } & Sesin pozisyonunu doğru biliyor. & 6 & 14,3 & Sesi doğru pozisyon ile çalıyor. & 1 & 2,4 \\
\hline & $\begin{array}{l}\text { Sesin pozisyonunu să el } 4 . \\
\text { parmağını basılı tutarak biliyor. }\end{array}$ & 12 & 28,6 & $\begin{array}{l}\text { Sesi sağ el 4. parmağını basılı } \\
\text { tutarak çalıyor. }\end{array}$ & 25 & 59,5 \\
\hline & Sesin pozisyonunu bilmiyor. & 24 & 57,1 & Sesi çalamıyor. & 16 & 38,1 \\
\hline
\end{tabular}




\begin{tabular}{|c|c|c|c|c|c|c|}
\hline & Toplam & 42 & 100 & Toplam & 42 & 100 \\
\hline \multirow{4}{*}{$\mathrm{B} b$} & Sesin pozisyonunu doğru biliyor. & 5 & 11,9 & Sesi doğru pozisyon ile çalıyor. & 1 & 2,4 \\
\hline & $\begin{array}{l}\text { Sesin pozisyonunu sağ el } 4 . \\
\text { parmağını basılı tutarak biliyor. }\end{array}$ & 9 & 21,4 & $\begin{array}{l}\text { Sesi sağ el 4. parmağını basılı } \\
\text { tutarak çalıyor. }\end{array}$ & 24 & 57,1 \\
\hline & Sesin pozisyonunu bilmiyor. & 28 & 66,7 & Sesi çalamiyor. & 17 & 40,5 \\
\hline & $\begin{array}{c}\text { Toplam } \\
\end{array}$ & 42 & 100 & Toplam & 42 & 100 \\
\hline \multirow{4}{*}{ B } & Sesin pozisyonunu doğru biliyor. & 5 & 11,9 & Sesi doğru pozisyon ile çalıyor. & 3 & 7,1 \\
\hline & $\begin{array}{l}\text { Sesin pozisyonunu sağ el } 4 . \\
\text { parmağını basılı tutarak biliyor. }\end{array}$ & 17 & 40,5 & $\begin{array}{l}\text { Sesi sağ el } 4 \text {. parmağını basılı } \\
\text { tutarak çalıyor. }\end{array}$ & 17 & 40,5 \\
\hline & Sesin pozisyonunu bilmiyor. & 20 & 27,6 & Sesi çalamıyor. & 22 & 52,4 \\
\hline & Toplam & 42 & 100 & Toplam & 42 & 100 \\
\hline
\end{tabular}

Tablo 7'ye bakıldığında, flüt öğrencilerinin \% 4,8'inin $\mathrm{D} \#$ sesini bilișsel beceri açısından sol el 4. parmağını, \% 14,3'ünün de sol el 1. parmağını basmadan bildiği, devinişsel beceri açısından da \% 4,8'inin sol el 4. Parmağını, \% 7,1'inin de sol el 1. parmağını basmadan çaldığı anlaşılmaktadır. Öğrencilerin \% 4,8'inin Ebsesini bilişsel beceri açısından sol el 4. Parmağını, \%11,9'unun da sol el 1. parmağını basmadan bildiği, devinişsel beceri açısından da \% 11,9'unun sol el 4. parmağını basmadan çaldığı görülmektedir. Yine tabloya bakıldığında öğrencilerin \%21,4'ünün F\# sesini bilişsel beceri açısından, \%23,8'inin de devinişsel beceri açısından sağ el 2. parmak ile bildiği ve çaldı̆̆ı, \%19,0'ının Gb sesini bilişsel beceri açısından, $\%$ 23,8'inin de de devinişsel beceri açısından sağ el 2. parmak ile bildiği ve çaldığ \% 21,4'ünün G\# sesini bilişsel beceri açısından \% 19,0'ının da devinişsel beceri açısından sol el 1. parmağını basılı tutarak bildiği ve çaldığı, \% 4,8 oranlarıla ise $G \#$ sesini bilişsel ve devinişsel beceriler açısından sol el başparmağını basılı tutarak bildiği ve çaldı̆̆ anlaşılmaktadır. Tablodan elde edilen bir diğer buldu ise öğrencilerin Ab sesini \% 16,7 oranıla bilişsel beceri olarak, \% 14,3 oranıyla da devinişsel beceri olarak sol el 1. parmağını basılı tutarak bildiği ve çaldığı, \%7,1'inin de yalnızca devinişsel beceri olarak sol el başparmağını basılı tutarak çaldığı yönündedir. Flüt öğrencilerinin 3.oktav A\#, Bbve B seslerindeki becerilerine bakıldığında; bilişsel beceri açısından A\# sesinde \% 28,6'sının, Bbsesinde \% 21,4'ünün, B sesinde de \% 40,5'inin sesleri sağ el 4. parmağını basılı tutarak bildiği, devinişsel beceri açısından da $A \#$ sesinde \% 59,5'inin, Bbsesinde \% 57,1'inin ve B sesinde de \% 40,5'inin sesleri sağ el 4. parmağını basılı tutarak çaldıkları görülmektedir. Ayrıca tablodaki 3.oktav seslere ait verilere bakıldığında, seslerin büyük çoğunluğunda bilişsel ve devinişsel beceriler açısından flüt öğrencilerinin bilemedikleri ve çalamadıkları seslere rastlanıldığı görülmektedir.

Tablo 8. Flüt Öğrencilerinin Parmak Pozisyonlarına İlişkin Bilişsel ve Devinişsel Beceri Puanlarının Karşılaş̧tırılması

\begin{tabular}{|c|c|c|c|}
\hline Beceri Puanları & $\mathbf{n}$ & $\begin{array}{c}\text { Korelasyon } \\
\text { Katsayısı }\end{array}$ & $\mathbf{p}$ \\
\hline $\begin{array}{c}\text { Bilişsel Beceri Puanları } \\
\text { Devinişsel Beceri Puanları }\end{array}$ & 42 & 0,817 & $0,000^{*}$ \\
\hline
\end{tabular}

Güzel Sanatlar Liseleri flüt öğrencilerinin bilişsel beceri ve devinişsel beceri puanlarının karşılaştırıldığı Tablo 8'deki Spearman Korelasyon sonucuna göre, korelasyon katsayısı 0,817 ve p anlamlılık değeri 0,000 olarak bulunmuştur. Korelasyon katsayısının 0,70-0,89 arasında bir 
değer alması ölçümler arasında yüksek düzeyde bir ilişki olduğunu ve p değerinin de 0,05 anlamlılık değerinden küçük olması $(p=0,000)$ flüt öğrencilerinin bilişsel beceri puanları ve devinişsel beceri puanları arasında anlamlı ve yüksek düzeyde bir ilişki olduğunu göstermektedir.

Tablo 9. Flüt Öğrencilerinin Okumakta Oldukları Sınıf İle Parmak Pozisyonlarına İlişkin Bilişsel ve Devinişsel Beceri Puanlarının Karşılaştırılmasıı

\begin{tabular}{|c|c|c|c|c|c|}
\hline Beceri & Grup & $\mathbf{n}$ & $\begin{array}{c}\text { Sira } \\
\text { Ortalaması } \\
\end{array}$ & $\mathbf{U}$ & $\mathbf{p}$ \\
\hline Bilişsel & $\begin{array}{l}\text { 11. Sinif } \\
\text { 12. Sinif }\end{array}$ & $\begin{array}{l}21 \\
21\end{array}$ & $\begin{array}{l}21,60 \\
21,40\end{array}$ & 218,500 & 0,960 \\
\hline Devinişsel & $\begin{array}{l}\text { 11. Sinif } \\
\text { 12. Sinif }\end{array}$ & $\begin{array}{l}21 \\
21\end{array}$ & $\begin{array}{l}21,86 \\
21,14\end{array}$ & 213,000 & 0,850 \\
\hline
\end{tabular}

$\mathrm{p}=0,960>0,05$ Mann Whitney U Testi (Bilişsel)

$\mathrm{p}=0,850>0,05$ Mann Whitney U Testi (Devinişsel)

Tablo 9 incelendiğinde, flüt öğrencilerinin öğrenim görmekte oldukları sınıf ile parmak pozisyonlarına ilişkin bilişsel $(p=0,960>0,05)$ ve devinişsel $(p=0,850>0,05)$ beceri puanları arasında anlamlı bir ilişkinin olmadığı görülmektedir. Bu durum, öğrenim görmekte olunan sınıf değişkeninin ses elde etmede kullanılan parmak pozisyonlarına ilişkin bilişsel ve devinişsel beceriler üzerinde herhangi bir etkisinin olmadığını ortaya koymaktadır.

Tablo 10. Flüt Öğrencilerinin Flüt Eğitimi Alma Süreleri İle Parmak Pozisyonlarına İlişskin Bilişsel ve Devinişsel Beceri Puanlarının Karşılaştırılması

\begin{tabular}{ccccccc}
\hline Beceri & Grup & $\mathbf{n}$ & $\begin{array}{c}\text { Sura } \\
\text { Ortalaması }\end{array}$ & Ki-Kare & df & p \\
\hline \multirow{2}{*}{ Bilişsel } & $1-3$ yıl & 24 & 22,63 & & & \\
& $4-6$ yll & 17 & 20,88 & 2,070 & 2 & 0,355 \\
& 7 yll ve üzeri & 1 & 5,00 & & & \\
\hline \multirow{2}{*}{ Devinişsel } & $1-3$ yıl & 24 & 23,23 & & \\
& $4-6$ yll & 17 & 20,18 & 3,103 & 2 & 0,212 \\
& 7 yll ve üzeri & 1 & 2,50 & & & \\
$\mathrm{p}=0,355>0,05$ Kruskal Wallis Testi (Bilisssel) \\
$\mathrm{p}=0,212>0,05$ Kruskal Wallis Testi (Devinişsel)
\end{tabular}

Tablo 10'a bakıldığında, flüt öğrencilerinin flüt eğitimi alma süreleri ile parmak pozisyonlarına ilişkin bilişsel $(\mathrm{p}=0,355>0,05)$ ve devinişsel $(\mathrm{p}=0,212>0,05)$ beceri puanları arasında anlamlı bir ilişki olmadığı anlaşılmaktadır. Bu durum flüt eğitimi almakta olunan süre değişkeninin parmak pozisyonlarına ilişkin bilişsel ve devinişsel beceriler üzerinde bir etkisinin olmadığını ortaya çıkarmaktadır. 
Tablo 11. Flüt Öğrencilerinin Çalgılarını Sevme/Sevmeme Durumları İle Parmak Pozisyonlarına İlişsin Bilişsel ve Devinişsel Beceri Puanlarının Karşılaştırılmasıı

\begin{tabular}{|c|c|c|c|c|c|}
\hline Beceri & Grup & $\mathbf{n}$ & $\begin{array}{c}\text { Sira } \\
\text { Ortalaması }\end{array}$ & $\mathbf{U}$ & $\mathbf{p}$ \\
\hline Bilişsel & $\begin{array}{c}\text { Evet } \\
\text { Hayır }\end{array}$ & $\begin{array}{c}41 \\
1\end{array}$ & $\begin{array}{l}21,29 \\
30,00\end{array}$ & 12,000 & 0,481 \\
\hline Devinişsel & $\begin{array}{l}\text { Evet } \\
\text { Hayır }\end{array}$ & $\begin{array}{c}41 \\
1\end{array}$ & $\begin{array}{l}21,26 \\
31,50\end{array}$ & 10,500 & 0,407 \\
\hline
\end{tabular}

$\mathrm{p}=0,481>0,05$ Mann Whitney U Testi (Bilişsel)

$\mathrm{p}=0,407>0,05$ Mann Whitney U Testi (Devinişsel)

Tablo 11 incelendiğinde, flüt öğrencilerinin çalgılarını sevme/sevmeme durumları ile parmak pozisyonlarına ilişkin bilişsel $(p=0,481>0,05)$ ve devinişsel $(p=0,407>0,05)$ beceri puanları arasında anlamlı bir ilişkinin olmadığı görülmektedir.

\section{Tartışma, Sonuç ve Öneriler}

Güzel Sanatlar Liseleri flüt öğrencilerinin flütten ses elde etmede kullandıkları parmak pozisyonlarının bilişsel ve devinişsel beceriler açısından incelenmesinin amaçlandığı çalışmanın bu bölümünde, bulgulardan elde edilen sonuçlar tartışılarak aktarılmış ve konu ile ilgili çeşitli önerilerde bulunulmuştur.

Araştırmanın bulgularından yola çıkılarak, Güzel Sanatlar Liselerinde öğrenim görmekte olan flüt öğrencilerinin büyük çoğunluğunun parmak pozisyonları açısından sıkıntı yaşadıkları ve yanlış davranışlar geliştirdikleri sonucuna varılmıştır. $\mathrm{Bu}$ yanlış davranışlar bilişsel ve devinişsel beceriler açısından büyük benzerlikler göstermektedir. Gençel Ataman'ın (2016) flüt öğrencilerinde karşılaşılan yanlış parmak pozisyonu davranışlarının flüt eğitimcileri görüşleri doğrultusunda değerlendirildiği çalışmasında görüşme yapılan flüt eğitimcilerinin tümü, Güzel Sanatlar Liselerinde flüt eğitimi almakta olan ya da bu kurumlardan mezun olmuş öğrencilerde yanlış parmak pozisyonu alışkanlıklarını gözlemlediklerini belirtmişlerdir.

Araştırmanın sonuçlarına göre, flüt öğrencilerinin bilişsel ve devinişsel beceriler açısından 1. ve 2. oktavlarda en çok $F \# / G b, A \sharp / B b v e ~ D \sharp / E b$ seslerinde parmak pozisyonlarını yanlış bildikleri ve kullandıkları gözlenmiştir. Cluff’a (2006) göre, flüt öğrencilerinde özellikle 1. ve 2. oktav $\mathrm{F} \sharp / \mathrm{Gb}$ seslerini elde etmede yanlış davranışlarla karşılaşılmaktadır. Bu yanlış davranışlar öğrencilerin çoğunlukla bu sesleri elde etmek için sağ el 3. parmak yerine sağ el 2. parmağı kullanmaları şeklinde ortaya çıkmaktadır. Oysaki F\#/Gbsesleri, ton ve ses tınısının doğruluğunu sağlayabilmek açısından sağ el 3. parmağın kullanımı ile elde edilmektedir. Diğer yandan Wye (1988), Hummel (2014) ve Krantz'ın (2000) da belirttiği gibi F\#/Gbseslerini elde etmede tril parmağı olarak bilinen sağ el 2. parmak kullanımı pes, zayıf ve kapalı bir tona neden olmasindan dolayı tercih edilmemelidir. Ely ve Van Deuren'e (2009) göre 1. ve 2. oktavlardaki F\# seslerini elde etmede sağ 2. parmağın kullanımı özellikle çalgıya başlangıç aşamasında flüt öğrencilerinde sıklıkla karşılaşılan en önemli yanlış davranışlardandır. Bu pozisyon flütte alternatif parmak pozisyonudur ancak ton ve tını doğruluğunu sağlamak için hız gerektiren teknik pasajlar ve E- F\# trili dışında tercih edilmemelidir.

Araştırmada Güzel Sanatlar Liseleri flüt öğrencilerinin bilişsel ve devinişsel beceriler açısından 1. ve 2. oktav Bb/A\# seslerini yalnızca Bbya da yalnızca A\# pozisyonunu ile bildikleri ve çaldıkları sonucuna ulaşılmıştır. Gençel Ataman (2016), Krantz (2000) ve Rhyne'nin (n.d) de 
belirttikleri gibi 1.ve 2. oktav $\mathrm{Bb} / \mathrm{A} \#$ sesleri temel olarak farklı pozisyonlar kullanılarak elde edilmelidir. Ancak öğrencilerin çoğunluğu bu sesleri tek bir pozisyon kullanarak elde etmeye çalışmaktadır.

Araştırmada elde edilen bir diğer bulguya göre flüt öğrencilerinin büyük çoğunluğunun 2. oktav $\mathrm{D} \# /$ Ebseslerini bilişsel ve devinişsel beceriler açısından sol el 1. parmaklarını kapalı konumda tutarak bildikleri ve çaldıkları sonucuna ulaşılmışıır. Hummel (2014), Krantz (2002), Rhyne (n.d.) ve Wye’nın (1988) da çalışmalarında değindiği gibi 2. oktav $\mathrm{D} \# / E b$ seslerini elde etmede sol el 1. parmak perdesinin açı bırakılması gerekmektedir. Cluff (2006) da flüt öğrencilerinde 2. oktav parmak pozisyonları açısından en sık karşıllaştığı problemi, öğrencilerin 2. oktav $\mathrm{D} \sharp / \mathrm{Eb}$ seslerini 1. oktav $\mathrm{D} \sharp / \mathrm{Eb}$ pozisyonunda olduğu gibi sol el 1. parmağı kapalı pozisyonda tutarak elde etmeye çalıştıkları şeklinde açıklamaktadır.

Flütte 3. oktava ilişkin parmak pozisyonları diğer oktavlara göre karmaşık ve zordur. Buna bağlı olarak flüt eğitimi sürecinde de öncelikle 1. ve 2. oktavlara ilişkin pozisyonların öğretilmesinin nedenini bu durum oluşturmaktadır (Han \& Lee, 2014; Hummel, 2014). Krantz'in (2002) da belirttiği gibi flütün özellikle çalgı grupları ve orkestralarda tiz sesleri seslendirme görevi edinmiş olması ve çalgının ses sınırlarının bu duruma olanak sağlaması nedeniyle 3. oktava ilişkin sesler en az diğer oktavlara ilişkin sesler kadar büyük önem taşırlar. Ancak flüt öğrencilerinin 3. oktav sesleri elde etmede gerek bilişsel gerekse devinişsel beceriler açısından büyük sıkıntı yaşadıkları da bilinen bir gerçektir. Wye (1988) ve Gençel Ataman'a (2016) göre flüt öğrencilerinde özellikle 3. oktav Sol Diyez, A \#/ Bb, B ve C seslerinin parmak pozisyonlarında yanlış bilgi ve davranışlara rastlanılmaktadır. Bu araştırmada da 3.oktav seslere ilişkin elde edilen verilerden yola çıkılarak flüt öğrencilerinin büyük çoğunluğunun bilişsel ve devinişsel beceriler açısından 3.oktav seslere ilişkin parmak pozisyonlarını bilemedikleri ve çalamadıkları sonucuna varılmıştır. Oysaki Güzel Sanatlar Liseleri flüt kitapları incelendiğinde tüm oktavlara ilişkin parmak pozisyonlarının 9.sınıf flüt ders kitabında yer aldığı bilinmektedir (Nacaroğlu, Vela Kalkan ve Güven 2018). Araştırmada böyle bir sonuca varılmış olması, 11. ve 12. sınıf flüt öğrencileri için önemsenmesi gereken bir sorun olarak görülmektedir.

Beceri öğreniminde bilişsel davranışların devinişsel davranış kazanma üzerinde önemli bir etkisi bulunmaktadır (Demirhan ve Bağırgan, 1993). Bu bağlamda çalışmanın sonuçlarına göre flüt öğrencilerinin bilişsel beceri puanları ve devinişsel beceri puanları arasında anlamlı ve yüksek düzeyde bir ilişki olduğu görülmektedir. $\mathrm{Bu}$ durum, flüt öğrencilerinin bilişsel ve devinişsel beceriler açısından yüksek düzeyde benzer davranışlar sergiledikleri sonucunu destekler niteliktedir.

Elde edilen bulguların çeşitli değişkenlerle ilişkilerinin araştırılması bilimsel çalışmalarda sıklıkla rastlanılan bir durumdur. Örneğin; Topoğlu (2014), Piji Küçük (2010), Tunçeli (2013), Birol (2005) ve Özdemir ve Yöndem (2011) çalışmalarında özyeterlik inancı, sınav kaygısı, benlik saygısı, çalgı başarısı, iletişim becerisi, tutum, problem çözme becerisi, akademik başarı ve çalgı dersleri gibi konuların çeşitli değişkenler açısından incelenmesine yer vermişlerdir. $\mathrm{Bu}$ çalışmalara göre incelenen değişkenlerin bazılarının söz edilen konular üzerinde etkilerinin olduğu bazılarının ise olmadığı sonuçlarına ulaşılmıştır. Bu bağlamda araştırmada flüt öğrencilerinin parmak pozisyonları ile ilgili bilişsel ve devinişsel becerileri ile öğrencilerin okumakta oldukları sınıf, flüt eğitimi alma süreleri ve çalgılarını sevme/sevmeme durumlarının incelenmesine de ver verilmiştir. 12. sınıf öğrencilerinin 11. sinıflara göre daha donanımlı olabilecekleri, daha uzun bir flüt eğitim sürecinin daha fazla tecrübeyi beraberinde 
getirebileceği ve çalgıya yönelik sevgi düzeyinin çalgıya olan ilgiyi arttırabileceği düşünüldüğünde bu değişkenlerin bilişsel ve devinişsel beceriler üzerinde olumlu etki yaratabileceği akla gelmektedir. Oysaki araştırmada, belirlenen değişkenlerin parmak pozisyonlarına yönelik bilişsel ve devinişsel beceriler üzerinde herhangi bir etkisinin olmadığ 1 sonuçlarına varılmıştır.

$\mathrm{Bu}$ sonuçlardan hareketle,

1- Güzel Sanatlar Liseleri flüt öğretmenlerinin, flüt öğrencilerine seslere ilişkin parmak pozisyonlarını öğretirken ulusal ve uluslararası flüt metodlarında yer alan parmak pozisyon tabloları hakkında bilgi vermeleri,

2- Güzel Sanatlar Liseleri flüt öğretmenlerinin parmak pozisyonları açısından daha bilinçli ve takip edici davranmaları,

3- Flüt sanatçılarının ve flüt öğretim elemanlarının mesleki müzik eğitiminin verildiği ortaöğretim kurumları olan Güzel Sanatlar Liselerinde gerçekleştirdikleri atölye çalışmaları ve seminerlerde özellikle parmak pozisyonlarının doğru kullanımına örneklerle değinmeleri önerilmektedir.

Flüt Öğrencilerinin Ses Elde Etmede Kullandıkları Parmak Pozisyonlarının Bilişsel ve Devinişsel Beceriler Açısından İncelenmesi başlıklı çalışmanın yazım sürecinde bilimsel, etik ve alıntı kurallarına uyulmuş; toplanan veriler üzerinde herhangi bir tahrifat yapılmamış, karşılaşılacak tüm etik ihlallerde "Pamukkale Üniversitesi Eğitim Fakültesi Dergisi Yayın Kurulunun" hiçbir sorumluluğunun olmadığı, tüm sorumluluğun Sorumlu Yazara ait olduğu ve bu çalışmanın herhangi başka bir akademik yayın ortamına değerlendirme için gönderilmemiş olduğunu taahhüt ederim. 


\section{Kaynakça}

Almeida, A., Devillers, M. Chow, R., Smith, J. \& Wolfe, J. (2010). Practice makes less imperfect: the effects of experience and practice on the kinetics and coordination of flutists' fingers. Proceedings of the International Symposium on Music Acoustics, 1-5.

Altes, J. H. (1986). Celebre metode complete de flute. Paris: Editions Musicales Alphonse Leduc.

Atak Yayla, A. (2000). Güzel sanatlar eğitimi bölümü müzik eğitimi anabilim dall flüt eğitiminde öğrencilerin psikomotor alan hedef ve davranışlara ulaşma düzeyleri. Yayımlanmamış Yüksek Lisans Tezi, Pamukkale Üniversitesi Sosyal Bilimler Enstitüsü, Denizli.

Birol, A. (2005). Üniversite öğrencilerinin problem çözme becerileri ve akademik başarılarının çeşitli değişkenlere göre incelenmesi. Marmara Üniversitesi Atatürk Eğitim Fakültesi Eğitim Bilimleri Dergisi, 21, 75-88.

Boehm, T. (2011). The flute and flute playing in acoustical, technical and artistics aspects. New York: Dover Publications Inc.

Bresin, R. \& Battel, G. U. (2000). Articulation strategies in expressive piano performance. J. New Music Research, 29, 211-224.

Büyüköztürk, Ş. (2008). Sosyal bilimler için veri analizi el kitabı (9. baskl). Ankara: Pegem Akademi.

Cluff, J. (2006). Common flute student mis-fingerings. https://www.jennifercluff.com/misfingering.pdf Erişim tarihi: 06.12.2018.

Demirhan, G. ve Bagırgan, T. (1993). Bilişsel alan öğrenmelerinin devinişsel (psikomotor) alan erişisine etkisi. Spor Bilimleri Dergisi, 4(4), 17-31.

Ely, M.C. \& Deuren, A. E. (2009). Wind talk for woodwinds: a practical guide to understanding and teaching woodwind instruments. New York: Oxford University Press.

Gençel Ataman, Ö. (2017). Flüt eğitimcilerinin güzel sanatlar liseleri flüt öğrencilerinin parmak pozisyonlarına yönelik görüşleri. Ídil Dil ve Sanat Dergisi, 6 (32), 1835-1852.

Gürbüz, S. ve Şahin, F. (2016). Sosyal bilimlerde araştırma yöntemleri (3. baskı). Ankara: Seçkin Yayıncilık.

Han Y. \& Lee K. (2016). Detecting fingering of overblown flute sound using sparse feature learning. EURASIP Journal on Audio, Speech, and Music Processing, 2, 2-10.

Han, Y. \& Lee, K. (2014). Hierarchical approach to detect common mistakes of beginner flute players. 15th International Society for Music Information Retrieval Conference, 77-82.

Harrison, H. (1982). How to play the flute. London: EMI Music Publising.

Hummel, C. (2014). The 5 most common fingering mistakes.

https://drcatesflutetips.wordpress.com/2014/10/26/the-5-most-common-fingering-mistakes/ Erişim tarihi: 28.08.2018.

Karşal, E. (2015). Flüt metotu (başlangıç seviyesi), İstanbul: Pan Yayıncılık.

Kurtaslan H. (2011). Flüt öğretiminde kullanılan dil teknikleri üzerine bir inceleme. Journal of New World Sciences Academy Fine Arts, 6 (2), 236-249.

Krantz, L. (2002). Common misconceptions about the flute- flute teaching tips. http://www.larrykrantz.com/misconcp.htm Erişim tarihi: 28.08.2018.

Krantz, L. (2000). Bb's \& F\#'s -having a system- flute teaching tips. http://www.larrykrantz.com/bbf.htm Erişim tarihi: 28.08.2018.

Moratz, K. E. (2010). Flute for dumies. Indianapolis: Wiley Publishing Inc.

Nacaroğlu, D., Vela Kalkan, N. ve Güven, Z. (2018). MEB 9. slnıf flüt ders kitabı. Ankara: MEB Yayınları.

Özdemir, M. ve Yöndem, S. (2011). Müzik öğretmeni adayı gitar öğrencilerinin çalgı alan dersleri ve genel akademik başarı durumlarının bazı değişkenler açısından incelenmesi. Marmara Üniversitesi Atatürk Eğitim Fakültesi Ĕgitim Bilimleri Dergisi 33, 141-156. 
Özen, N. (2004). Çalgı eğitiminde yararlanılan müzik eğitimi yöntemleri. Gazi Eğitim Fakültesi Dergisi, 24 (2), 57-63.

Piji Küçük, D. (2010). Müzik öğretmeni adaylarının sınav kaygısı, benlik saygısı ve çalgı başarıları arasındaki ilişkinin incelenmesi. Ahi Evran Üniversitesi Eğitim Fakültesi Dergisi, 11(3), 37-50.

Rhyne, J. (n.d.). Making better flutist. children's music workshop. http://www.childrensmusicworkshop.com/instruments/flute/betterflutists/ Erişim tarihi: 12.12 .2018

Soytok, S. (2014). Güzel sanatlar liselerinde öğrenim gören flüt öğrencilerinin flüt eğitimine ilişkin görüşleri. Sanat Eğitimi Dergisi, 2 (1), 196-216.

Topoğlu, O. (2014)._Sınıf öğretmeni adaylarının müzik öğretimine yönelik özyeterlik inançlarının çeşitli değişkenler açısından incelenmesi. Journal of Human Sciences, 11(2), 730-743.

Tunçeli, H. İ. (2013). Öğretmen adaylarının iletişim becerileri ile öğretmenlik mesleğine yönelik tutumları arasındaki ilişkinin incelenmesi (Sakarya üniversitesi örneği). Pegem Eğitim ve Ögrretim Dergisi, 3(3), 51-58.

Tufan E. ve Güdek B. (2008). Piyano dersi tutum ölçeğinin geliştirilmesi. Gazi Üniversitesi Eğitim Fakültesi Dergisi, 28 (1), 75-90.

Uçan, A. (1994). Müzik eğitimi, temel kavramlar-ilkeler-yaklaşımlar. Ankara: Müzik Ansiklopedisi Yayınları.

Üstün, E. (2010). Eğitim fakülteleri güzel sanatlar eğitimi bölümleri müzik eğitimi ana bilim dallarında uygulanmakta olan bireysel çalgl flüt eğitiminde karşılaşılan teknik problemlerin incelenmesi. Yayımlanmamış Yüksek Lisans Tezi, Selçuk Üniversitesi Eğitim Bilimleri Enstitüsü, Konya.

Wye, T. (1988). Proper flute playing. London: Novello \& Company Limited.

Yokuş, H. ve Yokuş, T. (2010). Müzik ve çalgı öğrenimi için strateji rehberi 1. Ankara: Pegem Akademi. 


\section{Extended Abstract}

\section{Introduction}

Music education is a field of education in which cognitive, affective and psychomotor skills are interbedded in each other. Instrument training which has a very important place in music education is an educational aspect which covers psychomotor, affective and cognitive skills with the same importance. In instrument training; cognitive skills include learning terms of instrument and comprehending techniques required for playing instrument; affective skills include loving the instrument, having an attitude for studying with discipline about playing instrument and playing the instrument in normal life; psychomotor skills include using both hands co-ordinately while playing and acquiring behaviours to solve problems in instrument playing.

Boehm mechanism modern flute which is accepted as the most common member of the flute family today has an important place in orchestra and in instrument training. Flute training which is included within instrument training is a planned educational process between teacher and learner and learner acquires basic techniques, information and skills about flute during this process. It is aimed, during the process of flute training, to give learner basic information and skills about flute, introduce flute literature and improve skill of musical interpretation. Apart from these, correct position, holding, correct breathing, correct finger positioning, languagehand coordination and basic flute playing techniques are also the skills that flute students should learn. Every instrument has specific techniques. However, correct positioning of fingers, coordination of finger positions and correct transitions are the common features of nearly all instruments. The direction, width of blowing and correct transition between finger positions and movements are quite important for wind instruments. As for blowing pressure, every sound has a standard finger position for the flute as well. Therefore in producing sound by flute, the speed of air blown and finger positions for the sound to be obtained is of great importance. Comprehension of techniques about finger positions forms cognitive skills and positioning of both hands co-ordinately in order to produce sound forms psychomotor skills about finger positions.

In the flute, finger positions at $1^{\text {st }}$ and $2^{\text {nd }}$ octaves do not differ except for $C, C \# / D b, D$, $\mathrm{D} \# / \mathrm{E} b$. Sounds at $3^{\text {rd }}$ and $4^{\text {th }}$ octaves are, being different from other octaves, obtained through specific and more complicated finger positions. However it is quite common that some flute learners confuse finger positions though unwillingly and become unable to acquire the sound according to rules. These behaviours, which in fact can easily be recognized with a good musical perception, may cause adapting wrong finger position especially in the starting phases of flute playing and correction efforts of these positions may cause negative attitudes towards the instrument.

In our country music education is given in mainstream school such as Fine Arts High School for secondary grades, Education Faculties Department of Music Education, Fine Arts Faculties Music Departments and partially State Conservatories. One of the most important fields of music education in Fine Arts High School is instrument training. Flute training which is included in instrument training in Fine Arts High School is an important branch of this education given in these institutions. Finger positions which are used for getting sound from the flute are among the important basic skills to be acquired in the beginning stage of flute 
education both in cognitive and psychomotor sense. When it is considered that learners start flute training at Fine Arts High School in the sense of occupational music education, it becomes important to analyze skills about finger positions in the process of flute training in Fine Arts High School. In this sense the aim of this study is to analyze finger positions of flute learners at Fine Arts High School while using for acquiring sound in the sense of cognitive and psychomotor skills.

\section{Method}

The study universe is composed of 243 flute learners who receive flute education at 11 th and 12th classes of 62 Fine Arts High School in our country which give flute training. Sample group is composed of 42 flute learners at 11th and 12th classes at 12 Fine Arts High School chosen among 7 geographical regions with cluster sampling method in 2017-2018 Academic year spring semester. "Information Test for Finger Positions" and "Practice Study for Finger Positions" which were developed by the researchers were used as data collection tool. Frequency (f) and percentage (\%) values were used for the evaluation of finger positions of learners who form the sample group in obtaining 1st, 2nd and 3rd octave sounds in the sense of cognitive and psychomotor skills; Spearman Correlation was used in comparison of psychomotor and cognitive skill scores related to finger positions of flute learners in obtaining sound; Mann Whitney U test was used in comparison of grade of flute learners and status of loving/not loving their instrument and cognitive and psychomotor skill scores of their finger positions, Kruskal Wallis Test was used in comparison of period of flute training of learners and cognitive and psychomotor skill scores of their finger positions.

\section{Results and Discussion}

Based on the findings of study, it was determined that great majority of flute learner who study at Fine Arts High School have problems in the sense of finger positions used for acquiring sound and develop wrong behaviours. These wrong behaviours are quite similar in the sense of cognitive and psychomotor behaviours. According to the results of study, it was observed in the sense of cognitive and psychomotor skills that flute learners have wrong finger positions most in $\mathrm{F} \# / \mathrm{G} b, \mathrm{~A} \# / \mathrm{B} b$ and $\mathrm{D} \# / \mathrm{E} b$ sounds at 1 st and 2 nd octaves. In the study it was concluded in the sense of cognitive and psychomotor skills that flute learners in Fine Arts High School try to attain 1st and 2nd octave b flat/a sharp sounds only through b flat or only through a sharp positions. According to another result of the study, it was determined in the sense of cognitive and psychomotor skills that great majority of flute learners try to attain 2nd octave $\mathrm{d}$ sharp/e flat sound by closing index fingers of the left hand. Moreover, it was also concluded in the sense of cognitive and psychomotor skills that great majority of flute learners do not know finger positions about 3rd octave sounds. Another result obtained from the study is that there is a significant and high level of relation between cognitive and psychomotor skills of flute learners however variables such as grade of flute learners, duration of their flute training and status of loving/not loving their instruments have no effect on their cognitive and psychomotor skills about finger positions. 


\section{Ekler}

\section{Ek 1: Uygulama Çalışması Örneği}

\section{Uygulama Calıșması (Görüntü Kaydı) Örneği}

Sinıf:.

Öğrenci Sıra No:

Değerli flüt öğrencisi,

Aşağıdaki çalışma bilimsel bir araştırmaya veri toplamak amacı ile hazırlanmıştır. Aşağıda yazılı olan sesleri ağır tempoda çalmanız gerekmektedir. Bilmediğiniz sesleri atlayabilirsiniz. Bilmediğiniz sesleri atlarken öncelikle geçtiğiniz sesin altında yazılı olan numarayı söyleyiniz ve daha sonra sesi çalınız. Sesleri çalarken flüt öğretmeniniz tarafından görüntü kaydı yapılacaktır. Görüntü kaydında yalnızca sesleri elde etmede kullanacağınız parmak pozisyonlarına dikkat edilecektir. Çalışmada sizinle ilgili kişisel bilgilere yer verilmeyecek, ad ve soyadı gibi bilgileriniz araştırmacı tarafından bilinmeyecektir. Görüntü kaydında sınıfınız ve flüt öğretmeninizin size verdiği numara kullanılacaktır.

$\mathrm{Bu}$ çalışmaya karşı gösterdiğiniz titizlik ve yardımlarınızdan dolayı teşekkür eder, sevgilerimi sunarım.

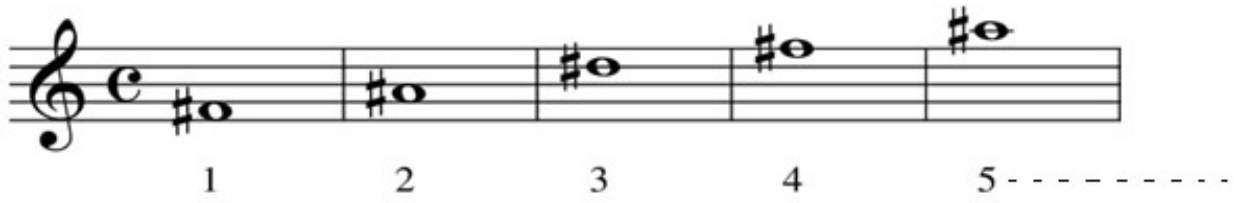




\section{Ek 2: Bilgi Testi Örneği}

\section{$\underline{\text { Bilgi Testi }}$}

Sinıf:.

Öğrenci Sıra No:

Değerli öğrenci; bu çalışmada, flütteki parmak numaraları; Başparmak (BP), 1. Parmak, 2. Parmak, 3. Parmak ve 4. Parmak olarak belirtilmiştir. Diğer yandan aşağıdaki şekilde parmak numaraları flüt mekanizması üzerinde gösterilmiş ve 2. sayfada 1. Oktav SOL sesini elde etmek için hangi parmakların kapatılacağı siyah renklerle belirtilerek örnek olarak verilmiştir. Sizden bu çalışmada 2.ve 3.sayfalarda yer alan seslerin, hangi parmakların kapatılarak elde edileceğini belirtmeniz istenmektedir. Bu nedenle, verilen seslerin yanlarındaki şekilleri parmak pozisyonlarına göre doldurarak belirtebilirsiniz. Bu çalışmaya karşı gösterdiğiniz titizlik ve yardımlarınızdan dolayı teşekkür eder, sevgilerimi sunarım.

\section{A-KISSiSEL BÍLGILER}

1- Sinıfiniz

11.Sinif

12. Sinif

2- Kaç yıldır flüt eğitimi alıyorsunuz?

3- Çalgınızı seviyor musunuz? Evet Hayir

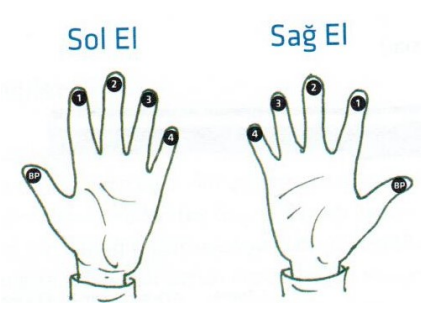

SOL EL PARMAKLAR SAĞ EL PARMAKLAR

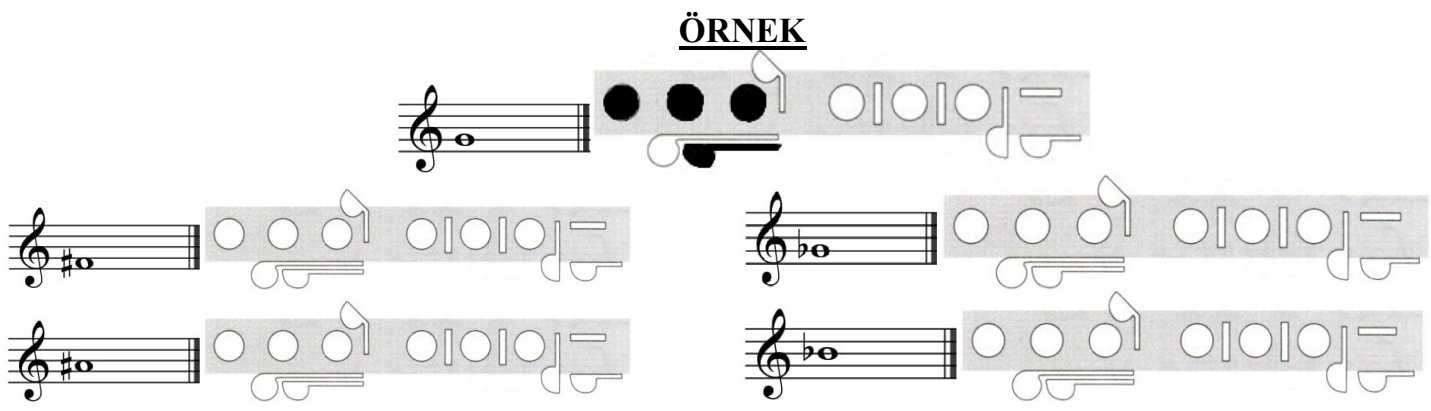




\section{Ek 3. Bilişsel ve Devinişsel Beceri Değerlendirme Tablosu Örneği}

\begin{tabular}{|c|c|c|c|}
\hline & Beceriler & Bilişsel Beceriler & Devinişsel Beceri \\
\hline \multirow{3}{*}{$\mathrm{F} \#$} & Doğru biliyor/çalıyor. & & \\
\hline & Sağ el 2. parmak ile biliyor/çalıyor. & -1 & \\
\hline & Bilmiyor/çalamıyor. & & $\square$ \\
\hline \multirow{3}{*}{$\mathrm{A} \#$} & Doğru biliyor/çalıyor. & $t$ & $\square$ \\
\hline & $\mathrm{Bb}$ pozisyonu ile biliyor/çalıyor. & & 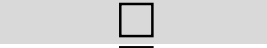 \\
\hline & Bilmiyor/çalamıyor. & & \\
\hline \multirow{3}{*}{$\mathrm{D} \#$} & Doğru biliyor/çalıyor. & & \\
\hline & Sol el 1. parmağı basılı tutarak biliyor/çalıyor. & $\square$ & $\square$ \\
\hline & Bilmiyor/çalamıyor. & $\square$ & $\square$ \\
\hline
\end{tabular}

